\title{
ECONOMIC INJURY LEVEL OF OIL PALM BUNCH MOTH, Tirathaba mundella WALKER FOR PEST MANAGEMENT RECOMMENDATIONS IN OIL PALM PRODUCTION
}

\author{
SU CHONG MING*; PATRICIA KING JIE HUNG*; KWAN YEE MING*; ZAKRY FITRI AB AZIZ* \\ and ONG KIAN HUAT*
}

\begin{abstract}
Oil palm bunch moth, Tirathaba mundella Walker is a notorious bunch feeding pest typically among oil palm aged 3-7 years old planted on peat. In order to manage the pest, an economic injury level (EIL) for the pest needs to be determined which could assist in decision-making if a control tactic is justified. In order to determine the EIL, the percentage of fertile oil palm fruitlets and oil to bunch content were determined for fruit bunches with different pest infestation severity. The severity was characterised based on the mean larvae present in fruit bunches and male inflorescences. The study found that the mean larvae count was positively correlated with the economic losses and number of parthenocarpic fruitlets. The overall oil extraction rate (OER) of moderate and severely infested fruit bunches was significantly reduced as compared to clean fruit bunches. Based on average crude palm oil (CPO) market price and production per hectare, an EIL for T. mundella was able to be estimated. This study suggested the EIL at $10 \%$ of oil palms per hectare moderately or severely infested. The finding of this study would benefit future pest management practice in oil palm plantation established on peatland.
\end{abstract}

Keywords: economic injury level, oil palm bunch moth, fruit set, oil to bunch, Tirathaba mundella.

Received: 13 November 2019; Accepted: 14 May 2020; Published online: 21 October 2020.

\section{INTRODUCTION}

Today, Indonesia and Malaysia are the world's biggest palm oil producers contributing $85 \%$ of the global palm oil supply which accounted for $34 \%$ of world vegetable oils consumption in 2018 (Kushairi et al., 2019). Compared with other oil bearing crops, oil palm is a highly efficient producer of vegetable oil. It needs less land, only 0.26 ha to produce $1 \mathrm{t}$ of oil compared with 2.2, 2.0 and 1.5 ha for soyabean, sunflower and rapeseed respectively (Wahid et al., 2011). On average, the oil palm industry contributes

\footnotetext{
Faculty of Agriculture and Food Sciences,

Universiti Putra Malaysia,

Bintulu Sarawak Campus,

P.O. Box 396, Jalan Nyabau,

97008 Bintulu, Sarawak, Malaysia.

E-mail: patricia@upm.edu.my
}

5\%-7\% of Malaysia's gross domestic product (GDP) with export revenue for the last five years averaging at RM 64.24 billion annually (Balu et al., 2018). However, the oil palm industry is facing multifaceted challenges; among them are severe pest infestation that adversely affected the oil palm yield.

Tirathaba mundella Walker, a menacing oil palm bunch moth that feeds on oil palm inflorescences as well as oil palm fruit bunches, are reported to severely negative impacted on palms especially those planted on peat and approaching maturity (5-7 years old) ( $\mathrm{Su}, 2016$; Lim, 2012; Lim et al., 2012). In severe infestation cases, abortion of male inflorescences and fruit bunches were reported $(\mathrm{Su}$, 2016). This will cause a substantial loss in yield. However, pest control measures are often costly. Therefore, it is important to recognise at which point will the pest population begins to cause sufficient 
damage to justify the time and expense of control measures. To a great extent, the answer depends on two fundamental pieces of economic information: (1) how much financial loss is the pest causing? and (2) how much will it cost to control the pest? Therefore, in this study, the economic injury level (EIL) of Tirathaba mundella (T. mundella) for an oil palm plantation was investigated to estimate the economic losses and determine the break out point where a pest control treatment must be carried out (Stejskal, 2003). The estimation of the EIL of T. mundella in oil palm plantation will enable the oil palm operators to fully appreciate the data of their pest field census as the capacity to make appropriate management decisions. A severity index is proposed in this study as a standard for field census and the EIL could be used as effective pest management strategy tool.

\section{MATERIALS AND METHODS}

\section{Assessment of Pest Infestation Severity in Mineral and Peat Estates}

Two young mature (7-year old) oil palm estates were selected as study sites. Estate A was established at peatland $\left(\mathrm{N} 4^{\circ} 02^{\prime} 57.660 \mathrm{E} 114^{\circ} 13^{\prime} 10.380\right)$ and Estate B was established on mineral soil ( $\mathrm{N} 4^{\circ} 07^{\prime}$ 43.248 E $113^{\circ} 58^{\prime} 49.188$ ), both under Miri district, Sarawak, Malaysia. The severity of the oil palm bunch moth, T. mundella's infestation was assessed, which covered an area of 5 ha per estate, with each replicate covered an area size of 1 ha. In both study sites, there were only one round of pesticide treatment applied in previous year and no treatment during the study period (Pin, 2018, Pers. Comm.). All fruit bunches and male inflorescences were collected from each assessment area and examined then categorised into three groups based on their infestation severity stages, namely light to clean, moderate and severe. Light to clean category was determined as fruit bunches or male inflorescences that did not show any obvious sign of infestation, shown in Figures $1 a$ and $1 b$ or had less than 25\% percentage of the surface covered with pest frass. Moderate infestation referred to a condition where $25 \%-50 \%$ of the surface of either a bunch or a male inflorescence was covered with pest frass (Figures $2 a$ and $2 b$ ) and the severe infestation was referred to a condition where more than $50 \%$ of the surface was covered by the frass (Figures $3 a$ and $3 b$ ).

\section{Larvae Count for Oil Palm Male Inflorescences and Fruit Bunches Based on Severity Categories}

Thirty oil palm male inflorescences and 30 fruit bunches in each category (light to clean, moderate and severe) were further assessed to evaluate the

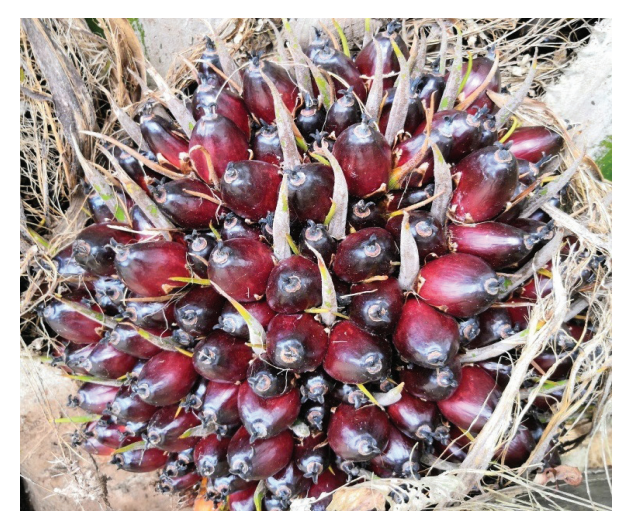

Figure 1a. Light to clean oil palm fruit bunch.

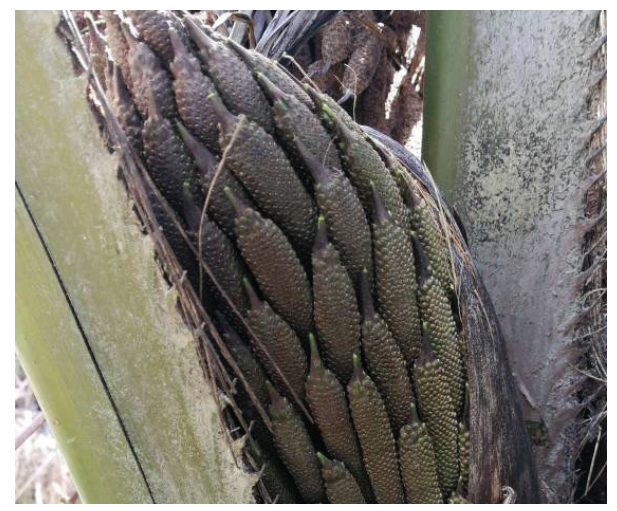

Figure 1b. Light to clean oil palm male inflorescence.

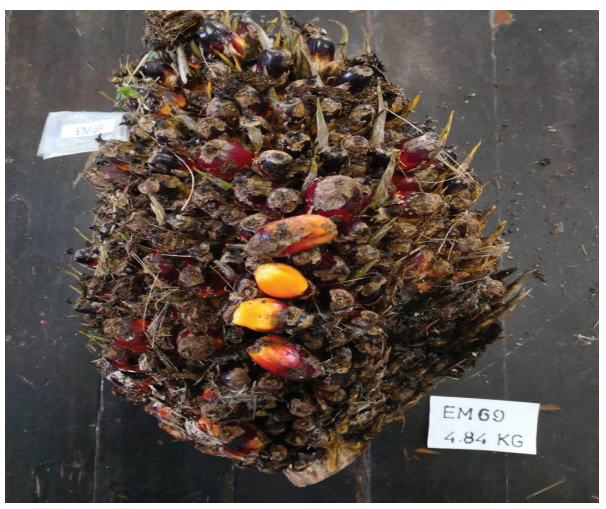

Figure 2a. Ripe oil palm fruit bunch with moderate oil palm bunch moth infestation.

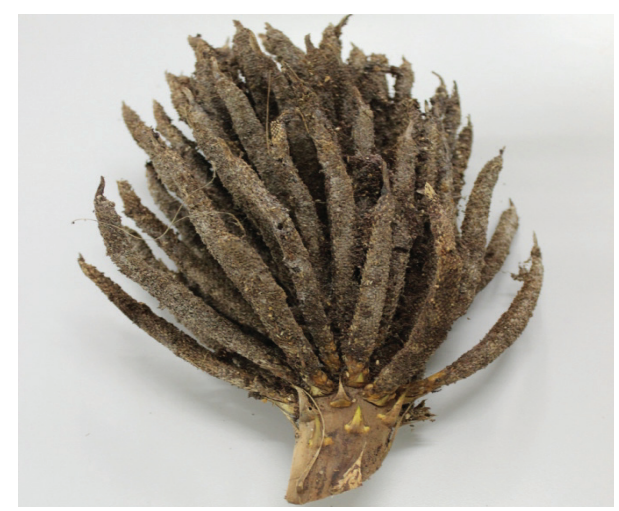

Figure 2b. Post-anthesis oil palm male inflorescence with moderate oil palm bunch moth infestation. 


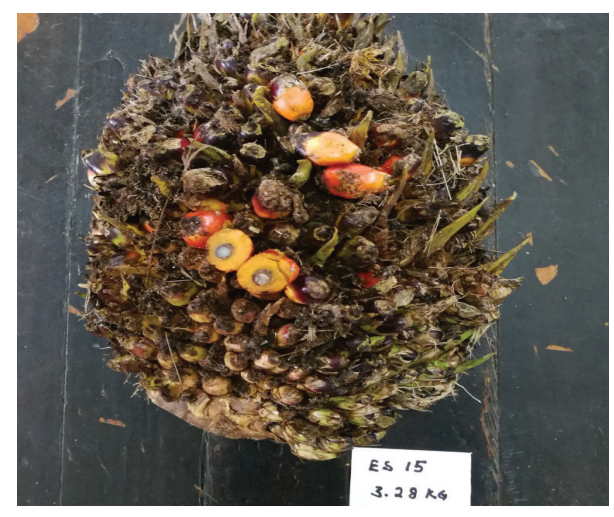

Figure 3a. Ripe oil palm fruit bunch with severe bunch moth infestation.

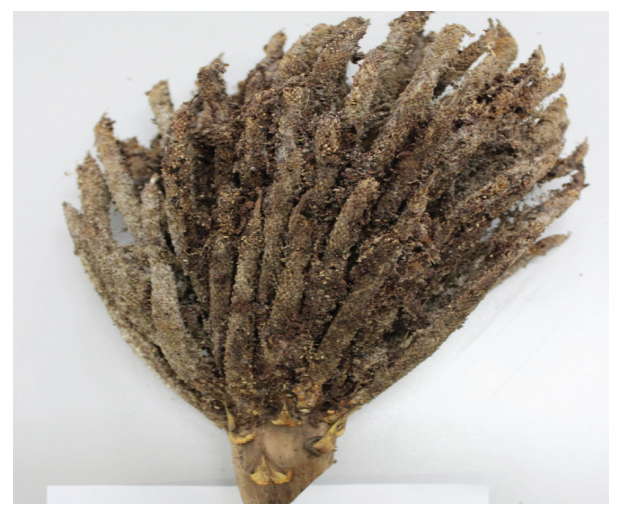

Figure 3b. Post-anthesis oil palm male inflorescence with severe bunch moth infestation.

average number of larvae present in each category. All fruit bunches and male inflorescences were dissected and the larvae residing in the sample were extracted. After each dissection, the sample was soaked in clean water for 5 min to capture the remaining larvae. Total number of larvae and their instar stages were recorded. The larvae count data were subjected to logarithmic transformation to normalise and after transformation, the larvae count data responded were subjected to analysis of variance using statistical analysis system (SAS) version 8.2.

\section{Percentage of Fruit Set for Oil Palm Fruit Bunches in Each Severity Categories}

Forty oil palm fruit bunches at their full ripening stages from each severity category, namely, light to clean, moderate and severe infestation were randomly sampled. The sampled bunches were weighed, dissected, and the bunch stalks were weighed. Then all the spikelets of fruitlets (Figure 4) were counted for their fertilised (Figure 5a) and parthenocarpic fruitlets (Figure $5 b$ ) ratio. Percentage of fruit set, which is the percentage of the total number of fertilised fruitlets to the total number of fertile plus parthenocarpic fruitlets in the sampled bunch (Sugih et al., 1996; Lawton, 1981; Harun and

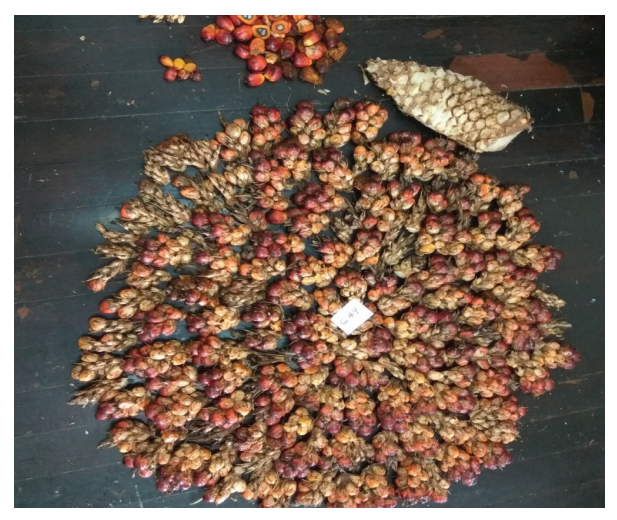

Figure 4. Spikelets of fruitlets after dissection.

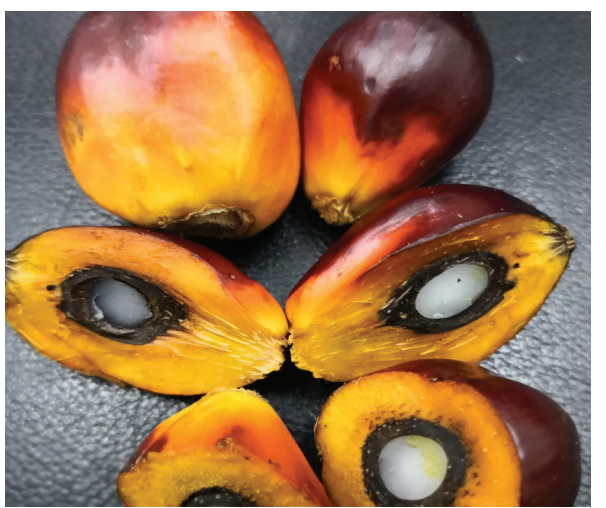

Figure 5a. Fertilised fruitlets: fully formed fruitlets with kernel and nut.

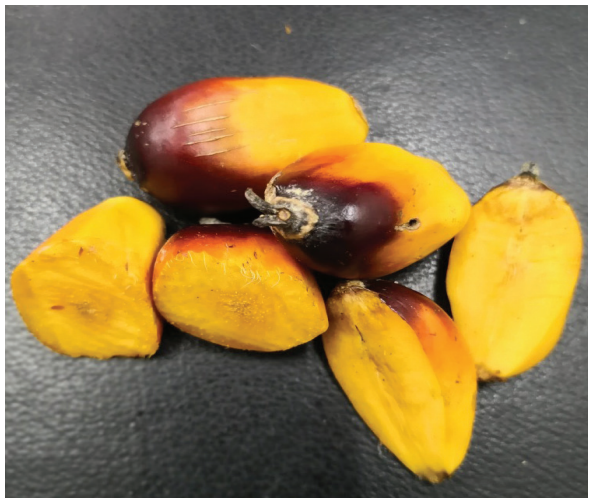

Figure 5b. Parthenocarpic fruitlets: fully formed fruitlets without kernel and nut.

Roslan, 2002) was calculated based on the following formula:

Percentage of fruit set $=($ total fertilised fruitlets $/$ total fruitlets) $\times 100 \%$

The percentage of fruit sets were subjected to ANOVA using SAS version 8.2 and the mean percentage of fruit sets for each category were tested for their significance difference using the Duncan New Multiple Range Test at a significant level of $\mathrm{p}<0.05$. 


\section{Bunch Weight and Oil Extraction Rate for Each Severity Category of Oil Palm Fruit Bunches}

The weight of fresh fruit bunches (FFB) from each severity category was recorded immediately after harvesting. The bunches were then dissected with an axe to separate the spikelets from the stalk. All the spikelets and loose fruits were weighed to get spikelets per bunch data. All the fruitlets were stripped from the spikelet and weighed to obtain the fruit to spikelet ratio. The fruitlets from each sample were then depericarped to separate the mesocarp fibre and the kernel nut. All the mesocarp from each sample was weighed before drying at $80^{\circ} \mathrm{C}$ overnight. The dried mesocarp was weighed after cooling to obtain the dry mesocarp to fruitlet ratio. The dried mesocarp was then ground using an electric grinder. The ground mesocarp fibre was then dried at $80^{\circ} \mathrm{C}$ for another $4 \mathrm{hr}$ to remove any remaining moisture. Oil was then extracted in $200 \mathrm{cc}$ Soxhlets for $10 \mathrm{hr}$ aggregate. After extraction, the samples were airdried overnight followed by oven dry at $80^{\circ} \mathrm{C}$ for another $2 \mathrm{hr}$ the next day. After drying, the samples were cooled in a desiccator before final weighing (Blaak et al., 1963). The oil in oil palm fruit mesocarp was calculated by the difference before and after drying. The formula for oil is shown below:

\section{Oil to bunch $=($ spikelet $/$ bunch $) \times($ fruitlet $/$ spikelet $) \times$ (dried mesocarp/fruitlet) x (oil/dry mesocarp) $\times 100 \%$}

The oil to bunch data obtained from each category of bunch was then compiled and subjected to ANOVA using SAS version 8.2 and the mean percentage of oil to bunch for each category was tested for their significance difference using the Duncan New Multiple Range Test at a significant level of $\mathrm{p}<0.05$.

\section{RESULTS AND DISCUSSION}

\section{Comparison of Tirathaba mundella Infestation Percentage between Mineral and Peat Oil Palm Estates}

Field assessments were carried out in two 7-year old palm estates. The severity of the infestation of T. mundella in peat estate was compared to mineral estate, as shown in Figure 6. Peat estate had significantly higher percentage of fruit bunches in moderate to severe categories than mineral estate. The mineral estate, on the other hand, had $100 \%$ of the collected fruit bunches in light to clean category.

This finding is expected as many studies have reported oil palm bunch moth is a major pest in oil palm plantations established on peat and sandy soils whereas mineral estates suffered in a lesser extent (Prasetyo, 2018). Tirathaba mundella feasts on male

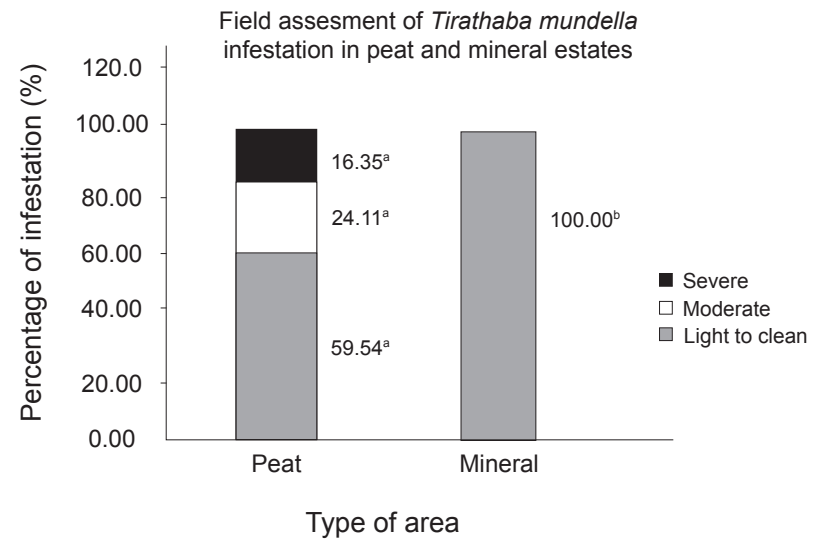

Figure 6. Difference of mean percentages of light to clean, moderate and severe infestation of oil palm fruit bunches between mineral and peat estates. Mean percentage with different superscripts were significantly different using T-test.

and female oil palm inflorescences in many peat estate (Lim, 2012; Wood and Ng, 1974; Su and Bong, 2017). It was reported that the first three months of oil palm inflorescences development were the most susceptible stage (Su, 2016). The larvae of T. mundella gain their entry through small openings of the female inflorescences when the sheaths had burst $(\mathrm{Ng}, 1977)$. The larvae build and move along in the tubes of silk which are attached with the granular faeces and other detritus. They feed on the ovules of flowers and plant tissues leaving behind all their faeces (Wood and $\mathrm{Ng}, 1974 ; \mathrm{Ng}, 1977$ ). When the damage was fresh, the faeces were in reddish colour (Figure $7 a$ ) and turned brownly black when aged (Figure $7 b$ ).

\section{Tirathaba mundella Infestation Severity Index}

The severity of T. mundella infestation was classed into three categories and the number of pest larvae found in the inflorescences as well as the fruit bunches based on each category were determined. The mean number of larvae found per male inflorescence in severe category was 24 (rounded up figure), 11 larvae in moderate category and five larvae in light to clean category (Table 1). The mean number of larvae found

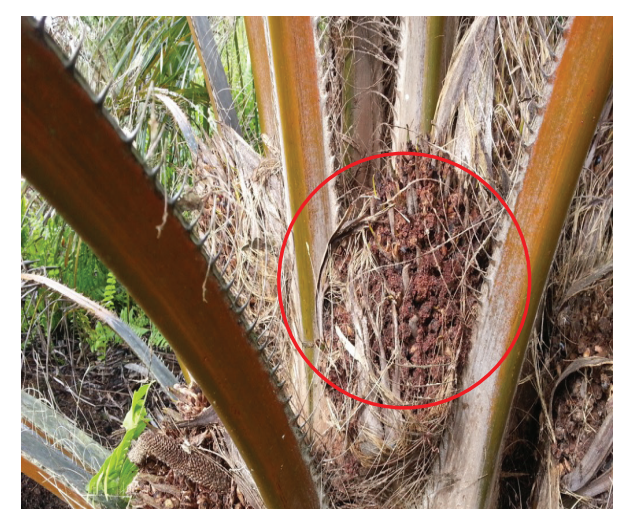

Figure 7a. Oil palm fruit bunches with severe new infestation covered by reddish faeces (red circle). 


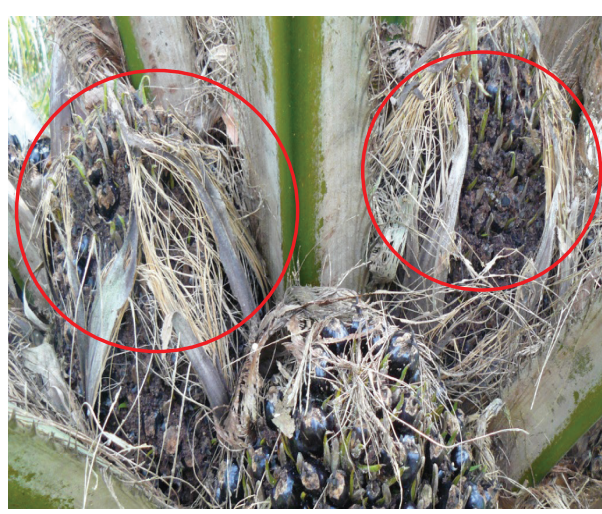

Figure $7 b$. Oil palm fruit bunches with severe old infestation covered by brownish black faeces (red circles).

in oil palm fruit bunches were 22 larvae in the severe category, 10 larvae in moderate category and two in light category (Table 1).

Table 1 could serve as a standard severity index that is practical and easy to be adopted by oil palm operator in their field census to estimate the pest population density. They only need to make visual estimation on the percentage of frass coverage on the fruit bunches as well as inflorescences (Figures 1 to 3 ) to determine the severity category and then estimate the larvae present in the field based on Table 1. A field census on pest density would soundly inform the management if a control measure should be taken. It is crucial as the pest management is usually costly.

An interesting observation was noted that the majority of the infested male inflorescence and fruit bunches were less than four months old where most of the inner fruitlets were still under development stage. This suggests that T. mundella preferred to infest on young fruit bunches (1-3 months old) than those more than four months old bunches where most of the fruitlets were fully formed.

The young larvae of T. mundella tunnelled through the soft tissue of young fruitlets and feed on the juicy embryo kernel and which later developed into fruitlets with a hollow centre due to prior destruction of the kernel $(\mathrm{Su}, 2016)$. Larvae of the bigger instar fed on 1-3 months old fruitlets, often resulting to scarring and pitting of the fruit surface ( $\mathrm{Ng}, 1977)$.

For oil palm male inflorescences that were infested with T. mundella, a depressions on the spikelets can be obeserved. Depending on the degree of damage, each spikelet would still develop until full anthesis stage where it would attract oil palm pollinators, Elaeidobius kamerunicus to visit and complete the pollination process ( $\mathrm{Su}$ and Bong, 2017).

For oil palm fruit bunches in moderate severity category, scarring and pitting were frequently observed on the fruitlets at the outer layer of the bunch while smaller fruitlets in the inner layer could become aborted due to destruction of the kernel. The fruit bunches in this severity category could continue to develop into maturity. The ripened bunches were with portions of undeveloped fruitlets and corky appearance as the outcome of mesocarp damage by the pest. For severely infested fruit bunches, the damage could lead to bunch abortion (Figure 8), and put the bunch development to a halt.

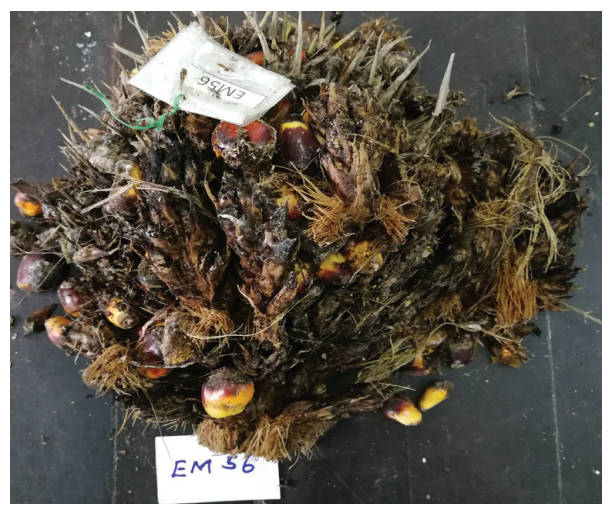

Figure 8. Aborted and rotten oil palm fruit bunch associated to severe Tirathaba mundella infestation.

Male inflorescence with severe infestation were noted to have most of their spikelets damaged and unable to develop into the anthesis stage. When less spikelets developed into the anthesis stage, it would attract less weevils to visit and indirectly negatively adversed the pollination process and resulted in poor fruit set. In some very severe cases when most of the spikelets were attacked, the male inflorescence would just abort and never reached anthesis stage (Su, 2016).

Reduced pollination due to the damages caused by T. mundella on the inflorescences would result in poor fruit set formation and subsequently affecting the oil palm yield. In addition to that, pest damage on the fruit bunches would directly impinge the palm oil yield quantity. Lim (2012) estimated that in a field with an outbreak of the pest and where most of the bunches were severely damaged, the yield losses could be as high as 50\%.

In order to assist in pest management decision making, an EIL was determined in this study. EIL which is one of the important component of integrated pest management (IPM) can be defined as the lowest population density that will cause economic damage (Stern et al., 1959).

The mean percentages of fertilised fully formed fruitlets, malformed small fruitlets and parthenocarpic fruitlets were compared among the three pest infestation severity categories as shown in Figure 9. Fruit bunches with fertilised fully formed fruitlets in moderate and severe categories were significantly lower as compared to light to clean category (Figure 9) and they also had more malformed small fruitlets and parthenocarpic 
TABLE 1. MEAN NUMBER OF Tirathaba mundella LARVAE FOUND ON BOTH OIL PALM FRUIT BUNCHES AND MALE INFLORESCENCES BASED ON DIFFERENT CATEGORIES OF INFESTATION SEVERITY

\begin{tabular}{lccccc}
\hline \multirow{2}{*}{$\begin{array}{l}\text { Tirathaba mundella } \\
\text { infestation severity } \\
\text { category }\end{array}$} & \multicolumn{2}{c}{ Percentage of pest faeces covered on surface } & & \multicolumn{2}{c}{ Mean number of larvae } \\
\cline { 2 - 3 } \cline { 5 - 6 } (\%) & Fruit bunch & Male inflorescence & & Fruit bunch & Male inflorescence \\
\hline Light to clean & $0-25$ & $0-25$ & & $1.67 \pm 0.60^{\mathrm{c}}$ & $4.86 \pm 1.64^{\mathrm{b}}$ \\
Moderate & $25-50$ & $25-50$ & & $9.93 \pm 1.95^{\mathrm{b}}$ & $10.86 \pm 3.08^{\mathrm{b}}$ \\
Severe & $>50$ & $>50$ & & $21.13 \pm 3.50^{\mathrm{a}}$ & $23.71 \pm 6.96^{\mathrm{a}}$ \\
\hline
\end{tabular}

Note: Mean with different superscripts were significantly different at $\mathrm{p}<0.05$ by Duncan Multiple Range Test.

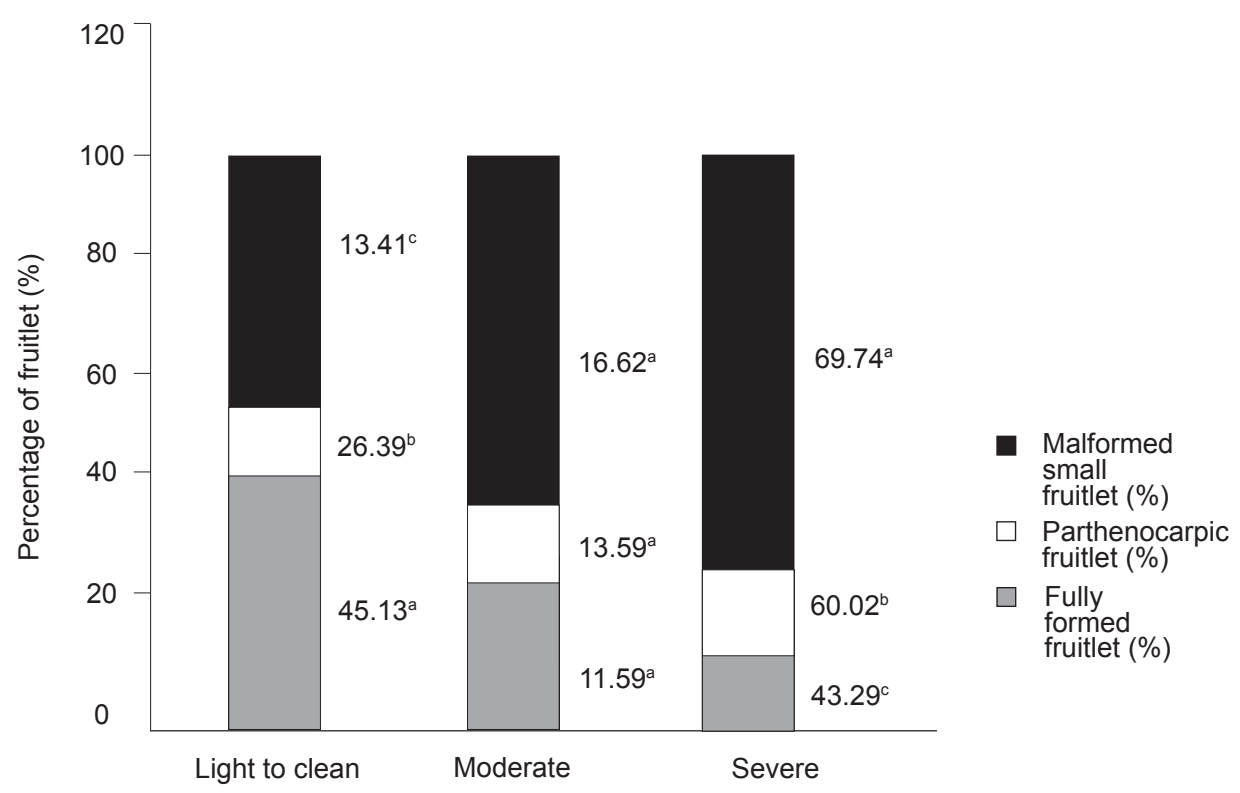

Figure 9. Percentage of fully formed, malformed and parthenocarpic fruitlets found on light to clean, moderate and severe infested fruit bunches. Mean percentage with different superscripts were significantly different at $p<0.05$ by Duncan Multiple Range Test.

fruitlets. This established the association of pest infestation severity with poor fruit set. This association was also noted in a study conducted in Indonesia by Prasetyo et al. (2018). Although poor fruit set formation has multifacted factors such as pollinators density, inflorescences sex ratio (Rao and Law, 1998; Syed and Saleh, 1987), the pest feeding on inflorescences is a undoubtedly the cause. Therefore controlling the pest population is crucial to maintain healthy fruit set formation.

Fruit bunch weight is used as one of parameters to measure oil palm plantation yield. The bunch weight for each severity categories were compared as shown in Table 2. The light to clean fruit bunches carried significantly heavier bunch weight than those in moderate and severe categories. Lower bunch weight means lower yield performance of an oil palm estate (Rao and Law, 1998).

Based on Rao and Law (1998), total yield is calculated based on the following formula:

Total yield $=$ Total number of bunches $\mathrm{x}$ average weight per bunch
Therefore, with the data of total number of bunches harvested in a light to clean, moderate or severely infested oil palm estate, the yield of that estate can be estimated based on average weight per bunch in Table 2. The total number of bunches collected is usually available and accurately recorded as harvesting payment is made based on the number of bunches harvested.

Table 2 shows the fruit bunches in severe category carried 50\% less weight than light to clean category. The loss of bunch weight is anticipated as there were significantly higher percentage of the malformed fruitlets in a bunch (Figure 9). The size of malformed fruitlets was significantly smaller than the normal fully-formed fruitlets. Loss in bunch weight has seriously impinged on both the yield per hectare and overall economy for the oil palm plantation.

The oil production per unit of a planted area is estimated by weight of FFB produced and its oil extraction rates (OER) in a mill (Donough et al., 2015; Julia et al., 2017). Therefore, another measurement to be taken into account to estimate the economic loss associated with pest infestation is the OER. 
TABLE 2. MEAN BUNCH WEIGHT FOR BUNCHES IN LIGHT TO CLEAN, MODERATE AND SEVERE INFESTATION CATEGORIES

\begin{tabular}{lcc}
\hline $\begin{array}{l}\text { T. mundella } \\
\text { infestation severity } \\
\text { category }\end{array}$ & $\begin{array}{c}\text { Percentage of pest } \\
\text { faeces covered on } \\
\text { fruit surface }(\%)\end{array}$ & $\begin{array}{c}\text { Mean bunch } \\
\text { weight }\end{array}$ \\
\hline Light to clean & $0-25$ & $6.56 \pm 0.33^{\mathrm{a}}$ \\
Moderate & $25-50$ & $4.49 \pm 0.19^{\mathrm{b}}$ \\
Severe & $>50$ & $3.79 \pm 0.19^{\mathrm{b}}$ \\
\hline
\end{tabular}

Note: Mean with different superscripts were significantly different at $\mathrm{p}<0.05$ by Duncan Multiple Range Test.

The OER is a useful management tool to assess the quantity of crude palm oil produced per area of planted oil palm and from there loss or gain of the oil palm enterprise could be estimated (Chang et al., 2003). Oil to bunch analysis on the other hand, could be done by any laboratory using very basic facilities. It would provide a basic data on intrinsic oil in the bunch which could be used to estimate the realised oil extraction rate commonly used by the industry to calculate the revenue. Table 3 shows the mean percentage of oil content in all three pest infestation severity categories. Both moderately and severely infested fruit bunches had significantly lower oil content than light to clean fruit bunches. This is related to the significantly higher percentage of malformed fruitlets found among fruit bunches in moderate and severe categories (Figure 9). Mostly malformed fruitlets carry very minimal or negligible oil content.

TABLE 3. THE OIL TO BUNCH PERCENTAGE FOR BUNCHES IN LIGHT TO CLEAN, MODERATE AND SEVERE INFESTATION CATEGORIES

\begin{tabular}{|c|c|c|}
\hline $\begin{array}{l}\text { Tirathaba } \\
\text { mundella } \\
\text { infestation } \\
\text { severity category }\end{array}$ & $\begin{array}{l}\text { Percentage of pest } \\
\text { faeces covered on } \\
\text { fruit surface }(\%)\end{array}$ & Oil to bunch \\
\hline Light to clean & $0-25$ & $23.63 \pm 0.80^{\mathrm{a}}$ \\
\hline Moderate & $25-50$ & $14.29 \pm 0.75^{\mathrm{b}}$ \\
\hline Severe & $>50$ & $11.93 \pm 1.03^{\mathrm{b}}$ \\
\hline
\end{tabular}

Note: Mean with different superscripts were significantly different at $\mathrm{p}<0.05$ by Duncan Multiple Range Test.

According to Chan (1981), the oil loss from mill processing averages about $8 \%$ of the oil recovered. Oil losses could incur due to many factors that include poor operation management such as uncollected loose fruits during routine harvesting intervals. Pertaining to this, a factor of 0.855 is suggested by the Institut de Recherche pour les Huile et Oleagineux (IRHO) to account for field and mill losses when converting laboratory oil to bunch figures to realised mill OER. The oil content of different categories of infested bunch was analysed and converted OER as shown in Table 4.
There was a significant reduction in OER for moderately and severely infested fruit bunches than light to clean fruit bunches. Significant reduction in oil extraction rate would result in monetary losses for a company (Farahida et al., 2017). In this study, the OER loss was estimated at $8 \%$ for moderately infested fruit bunches and $10 \%$ for severely infested bunches.

The average production of CPO per hectare is $4.01 \mathrm{t}$ whereas the production of palm kernel oil is $0.5 \mathrm{t} \mathrm{ha}^{-1}$ (Rao and Law, 1998; Donough et al., 1996). Based on 2019 average market price of CPO at RM $2100 t^{-1}$, and RM $2600 t^{-1}$ for crude palm kernel oil (MPOC, 2019), a $1 \%$ reduction in OER is equivalent to a loss of RM $97 \mathrm{ha}^{-1}$ (Table 5).

The average cost of a standard control measure using Bt. based insecticides is estimated as RM 77 ha $^{-1}$ (RM 35 for pesticides and RM 42 for labour cost). Therefore, a $0.8 \%$ drop of OER should alarm an intervention to be taken as the economic loss is at par with the control measure cost. Based on the finding of this study, if $10 \%$ of a hectare of an oil palm estate is moderately or severely infested by T. mundella, it will cause an average $0.8 \%-1 \%$ drop in OER, valued at RM 77.60-RM 97. Therefore, the EIL for T. mundella in oil palm estate is set at $10 \%$ of a hectare of an oil palm estate is moderately or severely infested by $T$. mundella. This is lower than the recommended EIL for T. rufivena proposed in 1991 by IRHO, which had set the EIL for at 30\% of palms with at least one bunch more than 50\% attacked (young plantings) and 60\% (older/mature planting). The difference may due to the variance in genus of insect pest. The proposed EIL can serve as a guideline for the management of T. mundella.

TABLE 4. POTENTIAL OIL EXTRACTION RATE (OER
REDUCTION FOR MODERATE AND SEVERE PEST
INFESTATION BASED ON BUNCH ANALYSIS AND CALCULATED OER

\begin{tabular}{lccc}
\hline $\begin{array}{l}\text { Infestation } \\
\text { category }\end{array}$ & $\begin{array}{c}\text { Oil content } \\
(\%) \text { (bunch } \\
\text { analysis) }\end{array}$ & $\begin{array}{c}\text { Calculated } \\
\text { OER }(\%)\end{array}$ & $\begin{array}{c}\text { Potential } \\
\text { OER } \\
\text { reduction } \\
(\%)\end{array}$ \\
\hline Light to clean & 23.63 & 20.20 & - \\
Moderate & 14.29 & 12.21 & -7.99 \\
Severe & 11.93 & 10.20 & -10.00 \\
\hline
\end{tabular}

TABLE 5. AVERAGE OIL PRODUCTION PER HECTAR AND MONETARY LOSS BASED ON 1\% OIL REDUCTION

\begin{tabular}{lccc}
\hline Oil type & $\begin{array}{c}\text { Average } \\
\text { production } \\
\text { per hectare (t) }\end{array}$ & $\begin{array}{c}\text { Reduction } \\
\text { of 1\% in oil } \\
\text { extracted (t) }\end{array}$ & $\begin{array}{c}\text { Loss in RM } \\
\text { (rounded up) }\end{array}$ \\
\hline $\begin{array}{c}\text { Crude palm } \\
\text { oil }\end{array}$ & 4.01 & 0.0401 & 84 \\
$\begin{array}{c}\text { Crude palm } \\
\text { kernel oil }\end{array}$ & 0.5 & 0.005 & 13 \\
\hline Total & & & 97 \\
\hline
\end{tabular}




\section{CONCLUSION}

Tirathaba mundella infestation is more profound in 7-year old oil palm peat estate than mineral estate of the same age. Using an easy to use $T$. mundella infestation severity index produced in this study, a field survey based on visual estimation of the percentage of faeces covered area on male inflorescences or fruit bunches can categorise an area into one of the three severity categories. Based on the category, the pest density can be roughly estimated as the mean number of larvae found corresponded to the severity categories. The bunch weight, the mean percentage of fruit set and oil to bunch were used to determine the overall oil extraction yield which translated into monetary value to estimate EIL. Based on this study, the EIL for T. mundella in oil palm estate is suggested at 10\% of a hectare of an oil palm estate under moderate or severe T. mundella infestation. Further research is recommended to investigate ways to sustainably reduce the pest population without harming the beneficial insects.

\section{ACKNOWLEDGEMENT}

The authors would like to thank Sarawak Oil Palms Berhad, Miri for support in the field work, and to University Putra Malaysia Bintulu Campus for the use of their facilities and technical supports. This research was funded by Grant Putra IPS GPIPS / $2017 / 9541400$.

\section{REFERENCES}

Balu, N; Azman, I; Norfadilah, H; Nazlin, I; Dayang, N S; Nik, A N I; Noraida, O; Kamalrudin, M S; Hassan, N A M and Kushairi, A (2018). Malaysia: 100 years of resilient palm oil economic performance. $J$. Oil Palm Res. Vol. 30(1): 13-25.

Blaak, G; Sparnaaij, L D and Menendez, T (1963). Breeding and inheritance in the oil palm (Elaeis guineensis Jacq.) Part II. Methods of bunch quality analysis. J. West African Institute of Oil Palm Research, 4: 146-155.

Chan, C O (1973). Some notes on the oil palm bunch moth (Tirathaba mundella Walk.) and its control. Advances in Oil Palm Cultivation (Wastie, R L and Earp, D A eds.). Incorporated Society of Planters, Kuala Lumpur. p. 396-401.

Chan, K S (1981). The estimation of mill oil losses. The Selangor Planters' Association Journal.

Chang, L C; Abdullah Sani, A R and Basran, Z (2003). An economic perspective of oil extraction rate in the oil palm industry of Malaysia. Oil Palm Industry Economic J. Vol. 3(1): 25-31.

Corley, R H V and Tinker, P B (2003). The Oil Palm. $4^{\text {th }}$ edition. 562 pp.

Donough, C R; Chew, K W and Law, I H (1996). Effect of fruit set on OER and KER: Results from studies at Pamol Estates (Sabah) Sdn Bhd. The Planter, 72(841): 203-219.

Donough, C R; Cock, J; Oberthur, T; Indrasuara, K; Rahmadsyah; Gatot, A R and Dolong, T (2015). Estimating oil content of commercially harvested oil palm fresh fruit bunches - A step towards increasing palm oil yields. Oil Palm Bulletin No. 70: $8-12$.

Farahida, Z; Nasuddin, O; Syahrizan, S; Zaini, M R and Muhammad, A B (2017). Fresh fruit bunch quality and oil losses in milling processes as factors that affect the extraction rate of palm oil. Int. J. Agriculture, Forestry and Plantation, 5: 99-103.

Harun, M H and Noor, M R M (2002). Fruit set and oil palm bunch components. J. Oil Palm Res. Vol. 14(2): 24-33.

Julia, A; Alawi, S; Mokhtar, M N; Baharuddin, A S and Daud, N M (2017). Development of palm oil extraction performance index (EPI) based on oil extraction rate (OER) and oil loss (OL). Pertanika J. Sci. and Technol., 25(S): 335-344.

Kushairi, A; Meilina, O A; Balu, N; Elina, H; Mohd Noor, I Z B; Razmah, G; Vijaya, S; Shamala, $S$ and Ghulam, K A P (2019). Oil palm economic performance in Malaysia and R\&D progress in 2018. J. Oil Palm Res. Vol. 31(2): 165-194.

Lawton, D M (1981). Pollination and fruit set in the oil palm (Elaeis guineensis Jacq.). Oil Palm in the Eighties (Malaysian Oil Palm Conference). p. 241.

Lim, K H (2012). Integrated pest management of Tirathaba bunch moth on oil palm planted on peat. The Planter, 88(1031): 97-104.

Lim, K H; Lim, S S; Parish, F and Suharto, R (2012). RSPO Manual on Best Management Practices (BMPs) for Existing Oil Palm Cultivation on Peat. RSPO, Kuala Lumpur.

Malaysian Palm Oil Council (MPOC) (2019). Monthly palm oil trade statistic. http: / / www.mpoc. org.my/monthly-palm-oil-trade-statistics-2019.

$\mathrm{Ng}$, K Y (1977). Bionomics of Tirathaba mundella, A Pest of Oil Palm. Master of Agricultural Science thesis, Universiti Malaya, Kuala Lumpur. 
Ng, S K; Helmut, V U and Hardter, R (2003). Botanical aspects of the oil palm relevant to crop management. Oil Palm Management for Large and Sustainable Yields. p. 13-24.

Pin, O K (2018). Personal communication. Sarawak Oil Palms Berhad, Miri, Sarawak.

Prasetyo, A E; Lopez, J A; Eldridge, J R; Zommick, D $\mathrm{H}$ and Susanto, A (2018). Long-term study of Bacillus thuringiensis application to control Tirathaba rufivena, along with the impact to Elaeidobius kamerunicus, insect biodiversity and oil palm productivity. J. Oil Palm Res. Vol. 30(1): 71-82.

Rao, V and Law, I H (1998). The problem of poor fruit set in parts of East Malaysia. The Planter, 74(870): 463-483.

Stern, V M; Smith, R F; Van Den Bosch, R and Hagen, K S (1959). The integration of chemical and biological control of the spotted alfalfa aphid: The integrated control concept. Hilgardia, 29(2): 81-101. DOI:10.3733/hilg.v29n02p081.

Stejskal, V (2003). Economic injury level and preventive pest control. Research Institute of Crop Production. J. Pest Science, 76: 170-172.

Su, C M (2016). Management of Oil Palm Bunch Moth (Tirathaba mundella Walker) in Young Mature Oil
Palm Plantation on Peat Soil in Sarawak, Malaysia. M. Sc. thesis, Universiti Putra Malaysia.

Su, C M and Bong, C F (2017). Effect of different insecticides on the survival of the oil palm pollinator, Elaeidobius kamerunicus (Coleoptera: Curculionodae). The Planter, 93(1100): 777-788.

Sugih, W; Heru, S; Ahmad, F and Thiagarajan, S (1996). Influence of rainfall, palm age and assisted pollination on oil palm fruit set in Riao, Indonesia. Proc. of the 1996 PORIM International Palm Oil Congress (Agriculture). PORIM, Bangi. p. 207-220.

Syed, R and Saleh, A (1987). Population of Elaeidobius kamerunicus Faust. in relation to fruit set. Proc. of the 1987 International Oil Palm /Palm Oil Conferences: Progress and Prospects - Module I Agriculture. p. 528534.

Wahid, M B; May, CY and Weng, C K (2011). Strategic direction in oil palm research. Further Advances in Oil Palm Research. MPOB, Bangi. p. 1-27.

Wood, B J (1968). Pests of Oil Palms in Malaysia and their Control. The Incorporated Society of Planters, Kuala Lumpur. p. 111-113.

Wood, B J and Ng, K Y (1974). Studies on the biology and control of oil palm bunch moth, Tirathaba mundella Walk. (Lepidoptera: Pyralidae). Malay. Agric. J., 49(3): 310-331. 